\title{
A visual perception study in landscapes subject to fires in South East Australia
}

\author{
Estudio de percepción visual en paisajes sujetos a quemas en el sureste de Australia
}

\author{
Paula Villagra Islas ${ }^{\text {a }}$ \\ ${ }^{a}$ Universidad Austral de Chile, Facultad de Ciencias, Instituto de Ciencias Ambientales y Evolutivas, \\ Valdivia, Chile, paula.villagra@uach.cl
}

\begin{abstract}
SUMMARY
Results of a visual perception study of landscapes subjected to prescribed burning regimes in South East Australia provided insight for improving fire management policies by considering the aesthetic dimension of landscapes. Preference and similarity data were collected during a series of photo-sorting interviews using photos as stimuli. Data were analyzed using a mix-method approach finding 10 landscape clusters. These were different in terms of the visual effect of different fire intensities over time and people's knowledge about fire management practices.
\end{abstract}

Key words: prescribed burns, landscape aesthetic, landscape management.

\section{RESUMEN}

Resultados de un estudio de percepción visual de paisajes sometidos a regímenes de quemas controladas en el sudeste australiano, sugieren como mejorar políticas de manejo del fuego al considerar la dimensión estética del paisaje. Datos de preferencia y similitud entre paisajes se recolectaron durante una serie de entrevistas $(\mathrm{N}=40)$ utilizando métodos de sorteo en los cuales se usaron fotografías como estímulos $(\mathrm{N}=56)$. Los datos se analizaron con métodos mixtos encontrando un total de 10 grupos de paisajes. Estos se diferenciaron por el efecto visual que provocan distintas intensidades de quemas en el paisaje a través del tiempo y por el conocimiento sobre las prácticas de fuego que tenían los entrevistados.

Palabras clave: quemas prescritas, estética del paisaje, ordenación del paisaje.

\section{INTRODUCTION}

Landscape aesthetic is one use of forests that is usually obscure for land managers; however, it has a great influence on the extent the community accepts and supports management practices (Gobster 1999, Ryan 2007). People can visualize the effect of management practices as part of a natural process or as a decline of landscape quality and such perceptions influence public response to management practices. This information is relevant to develop forest management policies.

In the USA, it is well known that the successful implementation of fire management programs in areas that people use for living and recreational purposes, rely on considering public response to fire effects on the landscape (Daniel et al. 2007). The outcomes of perception studies about the effects of fire on the landscape influence the development of planning and management programs of those areas. This is achieved by studying people's perception of the visual effects of management practices. Here, people discriminate between the aesthetics of landscapes. The outcomes of these studies can provide a set of landscape categories, with associated preference values and verbal descriptions, which suggest the extent that people appre- ciate the landscape from a scenic, ecological and/or utilitarian point of view, among others (Wilson 1984, Kaplan et al. 1998). Such types of results are influenced by the knowledge of management practices, familiarity with the study site and by the visual aspects of the landscape that change (Ryan 2005).

People's response to landscape change is explored here in the Australian context, where little research has been conducted on this topic. The site includes 300 hectares of Australian ecosystems at The Royal Botanic Gardens Cranbourne which are periodically subjected to prescribed burning regimes. Patches between 8 to 20 hectares are burnt in random locations within the site, twice a year to facilitate seed germination and plant growth.

\section{METHODS}

A mix-method approach (Villagra and Vergara 2012) was used to study people's perception of landscape change at The Royal Botanic Gardens Cranbourne. Participant groups were selected by convenience to assure that experts $(\mathrm{N}=19)$ and lay respondents $(\mathrm{N}=21)$ were interviewed. Within each group, respondents were selected randomly among visitors to the Royal Botanic Gardens Melbourne 
and staff members of the Department of Sustainability and Environment, Victoria, Australia (table 1). Both groups were different with respect to their knowledge of fire management practices, providing a good scenario to evaluate the extent that education influences perception. Experts were involved in fire management practices; in contrast, the lay respondents had other professions unrelated to fire management.

A detailed description of the methodology can be found elsewhere (Villagra and Vergara 2012). In short, fifty six photographs were taken at 14 different sites of the Royal Botanic Gardens Cranbourne which were burnt during 2007 and were used as stimuli to interview the two sample groups. Photos were taken from each site to the four cardinal directions and at four different times before and after fires during 2007 and 2008 (figure 1). Photographs were taken in April before the burns, three days after the burns, six months and one year after. The 56 photographs were shuffled and used to interview the participants to collect preference and similarity data. During the interview, peo-

Table 1. Description of participants. Descripción de participantes.

\begin{tabular}{|c|c|c|c|}
\hline Category & Sub-category & Expert group (EG) \% & Lay group (LG) \% \\
\hline \multirow[t]{2}{*}{ Gender } & Male & 63 & 35 \\
\hline & Female & 37 & 65 \\
\hline \multirow[t]{3}{*}{ Age group } & $18-25$ & 5 & 5 \\
\hline & $26-65$ & 95 & 75 \\
\hline & $65^{+}$ & 0 & 20 \\
\hline \multirow[t]{2}{*}{ Place of childhood development } & Urban area & 74 & 70 \\
\hline & Rural area & 26 & 30 \\
\hline \multirow[t]{5}{*}{ Visits to the study site } & Never & 73 & 80 \\
\hline & First time & 0 & 0 \\
\hline & Al least once a week or more & 0 & 0 \\
\hline & Al least once a month & 0 & 0 \\
\hline & A few times a year or less & 27 & 20 \\
\hline \multirow[t]{4}{*}{ Educationlevel } & Elementary school & 0 & 0 \\
\hline & Secondary highschool & 10 & 5 \\
\hline & Tafe/trade education & 10 & 20 \\
\hline & University/postgraduate degree & 80 & 75 \\
\hline
\end{tabular}

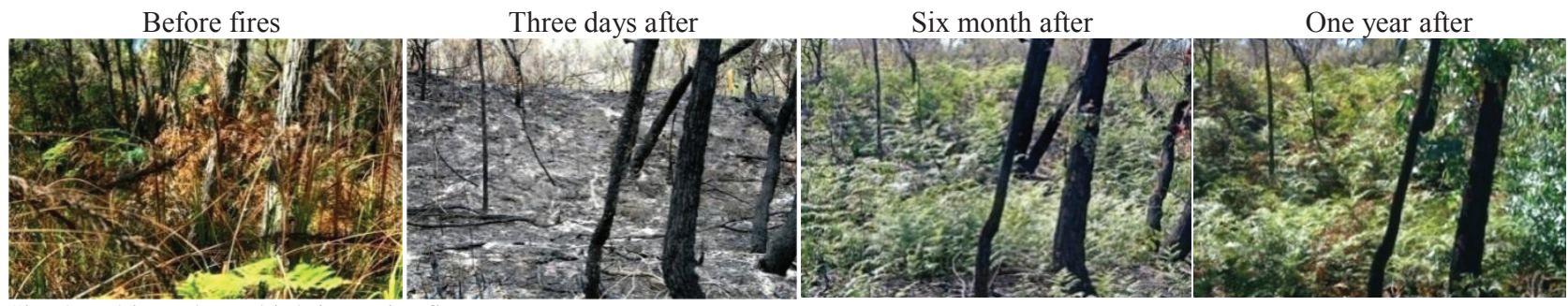

Site 3, subjected to a high intensity fire.
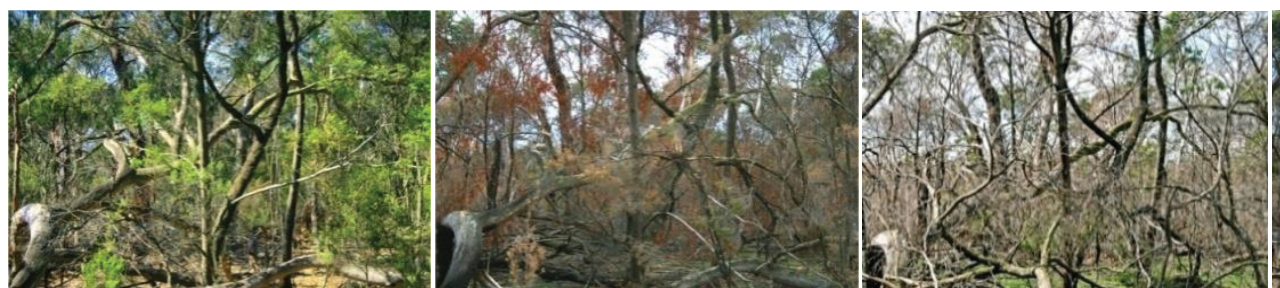

Site 11 , subjected to a low intensity fire.

Figure 1. Examples of the set of photographs taken from each of the 14 sites. Ejemplos del conjunto de fotografías tomadas en cada uno de los 14 sitios. 
ple were asked to sort photos by preference using a scale 1 to 7 , where 1 represents the lowest and 7 the highest value. Then, they were asked to sort the same photos by similarities in as many piles as they desired and provide verbal descriptions to characterize each pile they formed in their own words.

Descriptive statistics were used to analyze preference data. Aggregated mean and standard deviation preference values for each photo were used to graph variations of landscape preference for the 14 sites over time. This approach provided a preliminary overview of the grouping of the data in terms of landscape preferences (figure 2). Verbal responses were analyzed using content analysis to explore the most frequent landscape descriptors that people utilized to describe most and least preferred images. Hierarchical cluster analysis with between-group linkage method was performed, using the SPSS software V.15, to explore similarity data and the natural groupings of photographs and descriptors for each sample group. A Chisquare measure was used to determine distances between data points and values were neither transformed nor standardized.

\section{RESULTS}

Landscape preferences and descriptors. In most of the cases, preferences for landscapes decreased immediately after fires and then increased over time (figure 2). Most preferred landscapes were usually scenes photographed one year after the fires. $44 \%$ of the experts described these landscapes as 'healthy' and 'diverse' and $26 \%$ described them as formed by 'mixed species', finding the 'green' colours and 'the shape of the tree' appealing. Same images were most preferred for the respondents, however, for different reasons. $33 \%$ of the respondents suggested they liked these images the most because they are 'colourful', 'vibrant' and 'beautiful'.
Least preferred images were the scenes photographed right after fire $21 \%$ of the experts suggested that some of the least preferred scenes looked 'dry' and 'scrubby', because they had been subjected to a 'low intensity burn', or fire intensity not enough to have an effect on plant regeneration. Experts thought these landscapes provided 'bad accessibility', look 'damaged' and 'need fire' to regenerate the ecology. Instead, the respondents preferred landscapes that were recently burnt and illustrated in black and white the least. They suggested that these landscapes appeared 'dead' and 'ugly' in appearance. $24 \%$ of the respondents suggested that they looked 'dense' and 'messy' and does not present a means of exit ('lack of exit') for the public.

Landscape classification. Results of the hierarchical cluster analysis suggested a set of 10 landscape clusters, five for the experts ( $\mathrm{C} 1$ to $\mathrm{C} 5)$ and five for the respondents (C6 to $\mathrm{C} 10)$. These categories are illustrated in figure 3 and 4 , where clusters are named according to the verbal descriptors that respondents used the most to qualify photos in each cluster. In addition, the aggregated mean preference value (agg.M), standard deviation value (SD), the photo that represent the cluster the most (Rep.Photo) and the time when photos of each cluster were taken (Time) are indicated.

\section{DISCUSSION}

Visual images of landscape change over time (due to the effect of different fire intensities) clearly influence preferences (Gobster 1999). The post-fire regrowth of vegetation and changes in colour are the factors that affect landscape preferences over time with both groups. These results support the idea that people value the scenic aesthetic of landscapes in a similar way, regardless of their background (Kaplan 1998). Clusters C1 and C6 are the least preferred by both groups. These clusters include landscape images

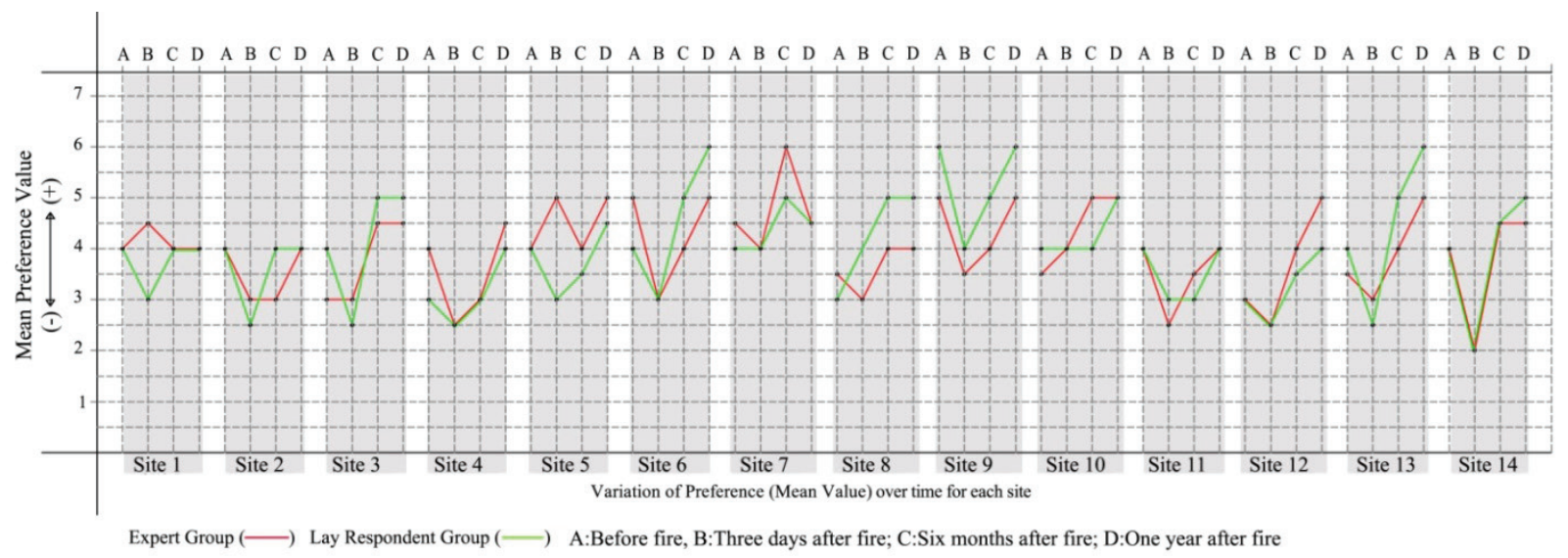

Figure 2. Variation of landscape preferences over a year. Variación de las preferencias del paisaje a lo largo de un año. 

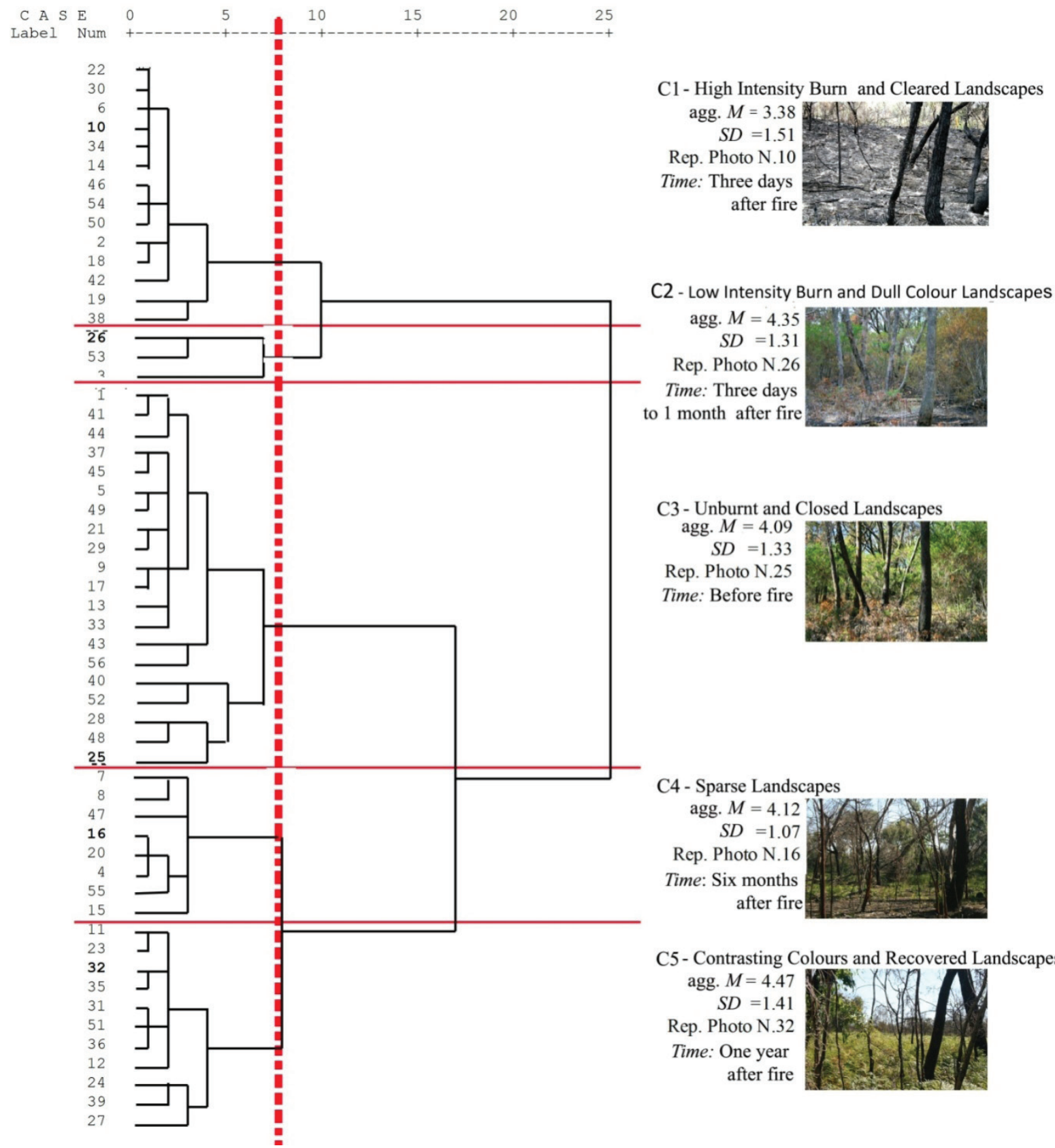

C2 - Low Intensity Burn and Dull Colour Landscapes agg. $M=4.35$ For $S D=1.31$

Rep. Photo N.26

Time: Three days

to 1 month after fire

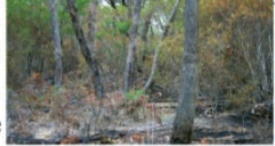

C3 - Unburnt and Closed Landscapes agg. $M=4.09$ $S D=1.33$

Rep. Photo N.25 Time: Before fire
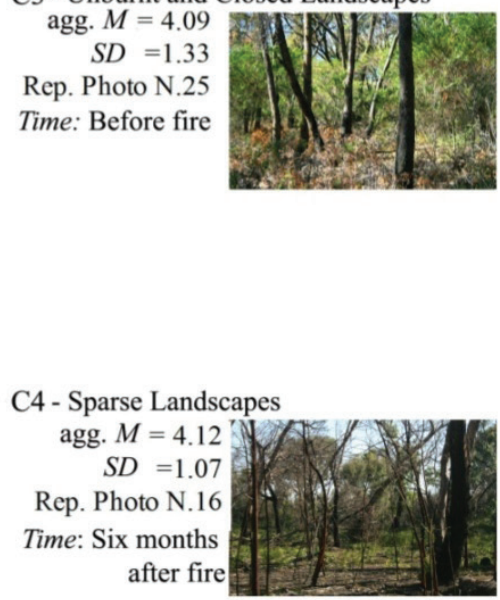

C5 - Contrasting Colours and Recovered Landscapes agg. $M=4.47$ $S D=1.41$

Rep. Photo N.32

Time: One year after fire

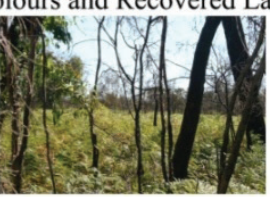

Figure 3. Dendogram of the expert group. Integrated results of the hierarchical clustering analysis, aggregated mean preference values and landscape descriptors. The between-group linkage method was used. Note: dull landscapes refer to landscapes that lack of bright and intense colours, and are opposed to landscapes with contrasting colours, that illustrate colours which are opposite to one another. Dendrograma del grupo de expertos. Resultados integrados del análisis jerárquico de agrupamiento, de los valores de preferencia agregados promedio y descriptores del paisaje. Se utilizó el método de relación entre grupos.

photographed three days after the burns, depict evidence of a large amount of burnt material and lack of green colour. According to the experts, these landscapes were subjected to a 'high intensity burn', or a very strong fire that cannot assure the regrowth of vegetation.

Instead, Clusters C4, C5, C9 and C10 are the highest preferred of all and include landscape scenes photographed a year and six months after the burn. Photos in these clus- ters depict ferns in bright-green and strong yellow colour and a few black trees that are sparsely distributed in the foreground area. Both study groups are clearly influenced by the colour and the sparse distribution of features in these scenes. However, only the experts see a hint of recovery after fire (C5) while the lay respondents may think some of these scenes are not even burnt (C10). Clearly, people's knowledge about management practices influence the 

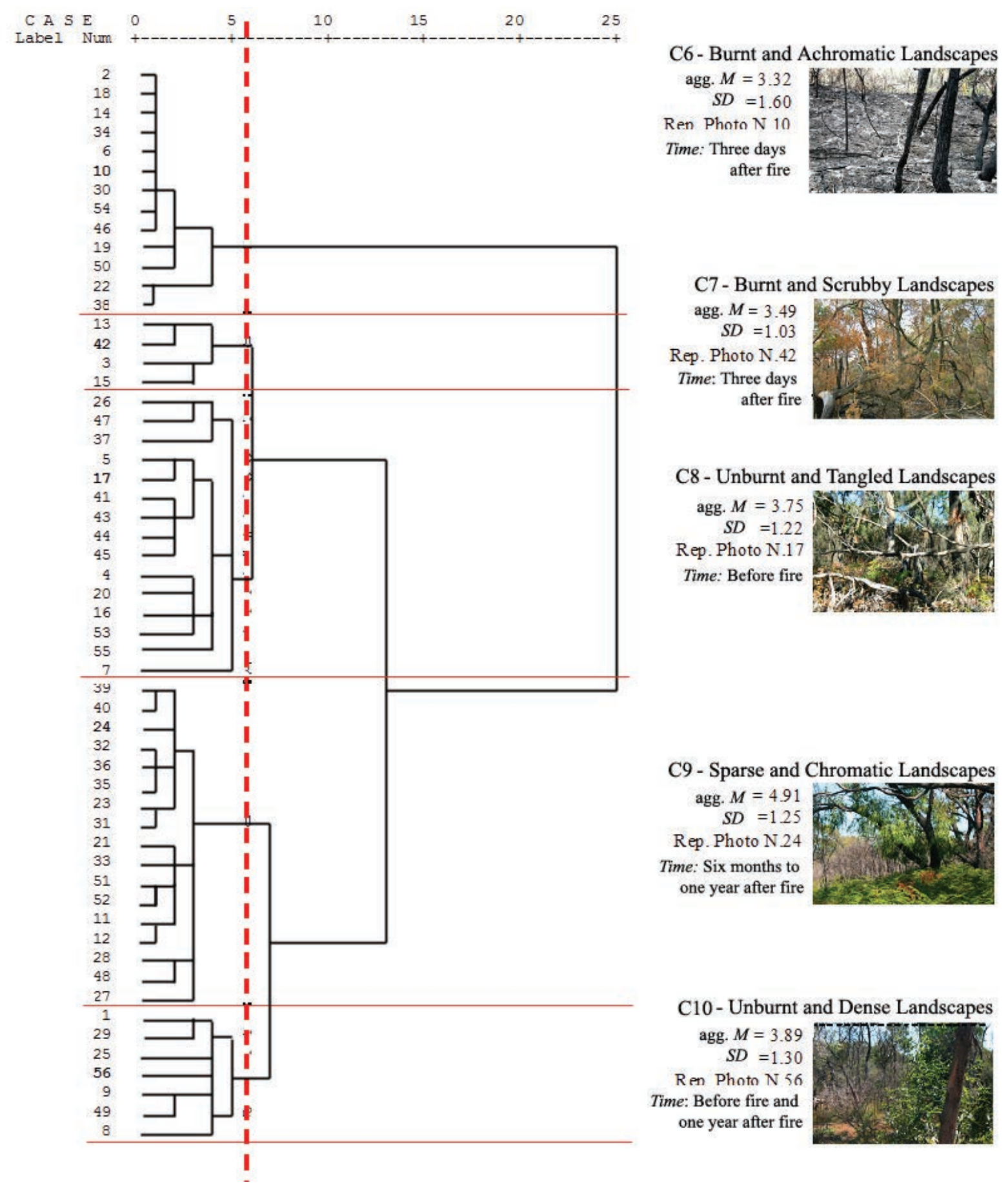

Figure 4. Dendogram of the lay respondent groups. Integrated results of the hierarchical clustering analysis, aggregated mean preference values and landscape descriptors. The between-group linkage method was used.

Dendrograma de los grupos no expertos. Resultados integrados del análisis jerárquico de agrupamiento, de los valores de preferencia agregados promedio y descriptores del paisaje. Se utilizó el método de relación entre grupos.

meaning people assign to landscapes as found in previous studies (Ryan 2005). Clusters C2 and C7 comprise images taken within days after fires and depict flammable material (yet unburnt) on the ground, such as old and dry vegetation. According to the experts, these scenes are subjected to a 'low intensity burn'. This means that the fire is neither enough to destroy the vegetation completely nor sufficient to stimulate the regrowth of new plant species. Instead, for the respondents these images are described only as 'burnt' and 'scrubby'.

People's discrimination of landscapes was found to be a useful approach to study similarities and differences 
in people's responses (Kaplan et al. 1998). It is clear that these cluster types evoke different landscape meanings for both groups. While experts evaluate landscapes in relation to both ecological and aesthetic values, responses from the respondents are mostly based on aesthetic values. Differences between landscape clusters illustrated in the dendograms suggest that the experts discriminate among landscapes mostly in relation to the effects of fire management practices.

\section{CONCLUSIONS}

Preference for landscapes subjected to prescribed burning regimes over time are similar between experts and the lay public, but the meanings both groups assign to these landscapes is different due to their degree of knowledge about fire management practices. This plays a key role in the discrimination of landscapes, as well as in the extent to which the communities' value landscape aesthetics subjected to controlled burning programs, that are aimed at both, conserving biodiversity and preventing devastating fires - as it is the case in Australia. Therefore, fire management policies should focus on enhancing the community knowledge about the process of prescribed fire and their beneficial effects in the long term.

Outcomes which are good for the ecology of landscapes as well as for the community can be assured by taking awareness of these types of results. In light of this, considerations such as increasing people's knowledge about the effects -aesthetic and ecological- of fire management practices over time can be taken. For example, strategies such as community visits to controlled burn sites and community involvement in designing conservation efforts should be encouraged. Such activities can increase the confidence and understanding of the community in the effects of prescribed burn programs.

\section{ACKNOWLEDGMENTS}

The author would like to thank the University of Melbourne in Australia, and the staff members of the Royal Botanic Gardens Cranbourne for their continuous support during the development of this study.

\section{REFERENCES}

Daniel T, M Carroll, C Moseley, C Raish. 2007. People, fire and forests. A synthesis of wildfire social science. Oregon, USA. Oregon State University Press. 221 p.

Gobster P. 1999. An ecological aesthetic for forest landscape management. Landscape Journal (18): 54-64.

Kaplan R, S Kaplan, R Ryan. 1998. With people in mind: design and management of everyday nature. Washington DC, USA. Island Press. 480 p.

Ryan R. 2005. Social science to improve fuels management: A synthesis of research on aesthetics and fuels management. Minnesota, USA. Department of Agriculture, Forest Service. 59 p.

Ryan R. 2007. Forest management and public perceptions in the northeast pine barrens: Attitudes toward wildfire hazard reduction strategies and defensible space (Draft Report). Amherst, MA, USA. Department of Landscape Architecture and Regional Planning, University of Massachusetts. 20 p.

Villagra P, G Vergara. 2012. Perceived visual landscape changes in a fire prone environment: A multi-method approach. Journal of Environmental Psychology (32): 144-157.

Wilson E. 1984. Biophilia. Cambridge, UK. Harvard University Press. 157 p.

Recibido: 24.05 .12

Aceptado: 10.10 .12 